\title{
Predation Pressure of Invasive Marsh Frogs: A Threat to Native Amphibians?
}

\author{
Fabien Pille*(D), Laura Pinto and Mathieu Denoël \\ Laboratory of Ecology and Conservation of Amphibians (LECA), Freshwater and Oceanic Science Unit of \\ Research (FOCUS), University of Liège, 4020 Liege, Belgium; laura.pinto.etu@outlook.fr (L.P.); \\ Mathieu.Denoel@uliege.be (M.D.) \\ * Correspondence: fabien.pille@uliege.be
}

check for

updates

Citation: Pille, F.; Pinto, L.; Denoël, M. Predation Pressure of Invasive Marsh Frogs: A Threat to Native Amphibians? Diversity 2021, 13, 595. https://doi.org/10.3390/d13110595

Academic Editor: Michael Wink

Received: 27 October 2021

Accepted: 16 November 2021

Published: 19 November 2021

Publisher's Note: MDPI stays neutral with regard to jurisdictional claims in published maps and institutional affiliations.

Copyright: (c) 2021 by the authors. Licensee MDPI, Basel, Switzerland. This article is an open access article distributed under the terms and conditions of the Creative Commons Attribution (CC BY) license (https:// creativecommons.org/licenses/by/ $4.0 /)$.

\begin{abstract}
Anurans have been introduced in many parts of the world and have often become invasive over large geographic areas. Although predation is involved in the declines of invaded amphibian populations, there is a lack of quantitative assessments evaluating the potential risk posed to native species. This is particularly true for Pelophylax water frogs, which have invaded large parts of western Europe, but no studies to date have examined their predation on other amphibians in their invaded range. Predation of native amphibians by marsh frogs (Pelophylax ridibundus) was assessed by stomach flushing once a month over four months in 21 ponds in southern France. Nine percent of stomachs contained amphibians. Seasonality was a major determinant of amphibian consumption. This effect was mediated by body size, with the largest invaders ingesting bigger natives, such as tree frogs. These results show that invasive marsh frogs represent a threat through their ability to forage on natives, particularly at the adult stage. The results also indicate that large numbers of native amphibians are predated. More broadly, the fact that predation was site- and time-specific highlights the need for repeated samplings across habitats and key periods for a clear understanding of the impact of invaders.
\end{abstract}

Keywords: amphibian decline; invasive alien species; predatory risk; size-selective predation; Pelophylax ridibundus; water frogs

\section{Introduction}

Freshwater habitats often have to cope with invasive alien species [1]. Although invaders may disturb native organisms in various ways, trophic interactions appear to be one of the main impacts, especially through predation [2-4]. Indeed, the introduction of novel predators induces additional predation pressure to which native organisms may not respond effectively [5]. Furthermore, invasive alien predators may reach high densities because of their life-history traits (e.g., high reproduction rates), various associations with humans, or through the absence of natural predators and parasites [6]. As a result, native species may suffer from excessive predation pressure, which influences the dynamics of their populations [7]. Therefore, predation by invasive alien species is an often-reported cause of native species decline [3], especially in fully or partially aquatic species [8,9].

The detrimental impacts of invasive alien species are worrying, particularly with regard to the vulnerable and declining native class of amphibians $[9,10]$. Nowadays, $16 \%$ of amphibians listed in the International Union for Conservation of Nature (IUCN) red list are threatened by invasive alien species [11], and since the 1980s, an increasing number of studies have emphasized the negative impact of invasive alien predators on native amphibian populations [3,4]. Interestingly, anurans are one of the most reported invaders $[4,12,13]$. Due to their ease of translocation, high reproduction rates, and generalist diet, invasive anurans have become a challenging issue for conservation efforts [14]. Predator-prey interactions between invasive alien anurans and natives can impact many species of higher, equivalent, or lower trophic rank [4]. For instance, invasive cane toads (Rhinella marina) are 
known to poison native predators that feed upon them [15] but to rarely feed on native amphibians [16]. Other widely introduced invasive amphibians, such as the American bullfrog (Lithobates catesbeianus) and the African clawed frog (Xenopus laevis), consume native amphibians, including metamorphosed anurans [17-20], tadpoles [19,21], newts [19] and, more rarely, eggs [22].

Although the ecological impacts of the most widely introduced anurans are now documented, there has been little quantitative assessment of predation across space and time. However, biological invasions may have contrasting effects, depending on localities and time periods (i.e., depending on the phenology of invaders and natives), indicating the need for information regarding temporal patterns at a large number of sites [6]. Furthermore, the risk posed by predation by invasive alien anurans may also depend on the biological traits of the invaders, such as body size, which may influence prey selection due to gape-size limitations [23]. Therefore, this trait should be integrated for predation assessments.

Despite their high prevalence in some parts of the globe, the predatory pressure of some major amphibian invaders has not been studied to date [24]. For instance, in Europe, the animal trade has resulted in multiple invasions of Pelophylax water frogs (Ranidae). Recent increases in introductions and expansion in recent decades in western Europe have made these species the most widespread amphibian invaders on the continent [25]. In particular, the marsh frog (P. ridibundus) is considered native only east of the Rhine but is now present in large parts of France, Belgium, Luxembourg, and Italy [25-30]. Particularly in invaded areas with sister Pelophylax species present, introductions have often led to complex and cryptic invasions only identifiable through genetic assessment. As a result, the ecological consequences of water-frog invasions have remained understudied and underestimated. More recent studies have considered the replacement of native Pelophylax water frogs to be a severe threat due to hybridogenetic replacement [31,32]. However, the other risks of these Pelophylax invasions for native amphibians have still not been investigated. In their natural range, the diet of marsh frogs has been studied in freshwater habitats and indicates little or no predation on native amphibians. Most reported cases were cannibalism of metamorphosed individuals and tadpoles [33-38], whereas newts, tree frogs, and tadpoles were rarely detected in the diet [39-42]. Furthermore, a recent behavioral observation also confirmed the ability of marsh frogs to forage on tree frogs [43]. These observations suggest that marsh frogs may also feed on native amphibians in invaded areas. This implies the need for integrative studies to quantify the predation pressure exerted by water frog invaders in colonized areas. One such area is the Larzac plateau in southern France [26], historically devoid of Pelophylax frogs [44]. P. ridibundus has now colonized a large part of the plateau and is still expanding ([26]; M. Denoël, pers. obs.). Due to the high amphibian diversity value of Larzac [44-46], these invasions raise concerns about their effect on populations of native amphibians. This study system therefore provides an ideal model with which to determine the predation risk posed by invasive water frogs.

In this context, this study aimed to provide a quantitative assessment of the occurrence of amphibians in the diet of invasive marsh frogs in their invaded range (Larzac) in a replicated design across space and time. More specifically, our objectives were to highlight the species at risk of predation, the importance of seasonality, and the role of the body size of the invaders. Because Pelophylax are successful invaders, we hypothesized that they exert a predatory pressure on the different life stages of the native taxa, including adult amphibians that may be potential prey, given the large body size of the invaders. Furthermore, we expected predation pressure to reach its maximum during the breeding period of native amphibians, when they massively join ponds.

\section{Materials and Methods}

\subsection{Study Area and Organisms}

The study took place on the Larzac karst plateau in southern France (Hérault, France; area delineated from $43^{\circ} 48^{\prime} \mathrm{N}$ to $43^{\circ} 54^{\prime} \mathrm{N}$ and from to $3^{\circ} 21^{\prime} \mathrm{E}$ to $3^{\circ} 33^{\prime} \mathrm{E}$; Supplementary Material Figure S1). The study area is mainly characterized by open, traditionally managed land- 
scapes surrounded by forests. It hosts a large number and diversity of ponds, primarily used for watering cattle and sheep and inhabited by several species of amphibians [44,47]. Multiple surveys in 85ponds in the 1970s showed that Larzac was historically devoid of any species of Pelophylax ([44]; J. Gabrion, pers. comm.). Native Pelophylax species were restricted to lower-elevation sites outside the Larzac region [48]. This area was subsequently invaded by Pelophylax marsh frogs at the end of the 20th century and possibly in the early 2000s ([26]; M. Denoël, pers. obs.). Direct translocations occurred in Larzac, as testified by local inhabitants (personal communications to $M$. Denoël and F. Pille). One previous genetic study identified marsh frogs in the studied area as lineages of Pelophylax ridibundus [26]. This species is also named Pelophylax fortis, according to debated nomenclatural revisions [49], but the traditional taxonomic assignment (i.e., P. ridibundus) is used here. Two morphologically cryptic lineages (the Balkan marsh frog P. kurtmuelleri and the marsh frog sensu stricto P. ridibundus) were genetically identified in Larzac populations, both of non-indigenous origin (i.e., from eastern/southeastern Europe [26]). As they show closely related phylogenetic divergence and are morphologically cryptic, these two lineages were studied as P. ridibundus sensu lato. Although Pelophylax perezi populations were found in southern France $[26,48]$, there were no populations in the surveyed area (C. Dufresnes, G. Mazepa and M. Pabijan, pers. comm.).

\subsection{Sampling and Prey Identification}

To gain a broad overview of the predation of invasive Pelophylax water frogs on amphibians, marsh frogs were sampled in 21 ponds (mean surface area $\pm \mathrm{SE}=158.94 \pm 34.98 \mathrm{~m}^{2}$ ) typically used to water cattle and surrounded by traditionally managed landscapes. Frogs were caught at dusk and early night manually or with dip nets during the active season from early April to the end of July 2019. Each pond was sampled monthly (i.e., four times over the whole study period). Frogs were kept individually in tanks and released within hours of capture. Frogs were identified individually using PIT-tags implanted in the back under the skin (Biolog-ID, $134.2 \mathrm{KHz}$; Agrident reader) to consider potential recaptures over time. PIT-tagging is an effective method for marking amphibians [50,51]. The snout-vent length (SVL) of each individual was measured from the tip of the snout to the end of the cloaca with a caliper. Only adult marsh frogs-that is, individuals with a minimum SVL of $50 \mathrm{~mm}$-were included in the sampled population (i.e., minimum SVL of males exhibiting nuptial callosities and vocal sacs in this study). Stomach contents were collected by flushing frog stomachs, following the method described by Solé et al. [52], by gently injecting water into the stomach using a rounded, soft silicone canula through the mouth, causing prey items to be regurgitated. Water was injected into stomachs using a sprayer to maintain a slow, continuous flow. This technique does not affect the survival or behavior of amphibians [53]. No individuals were hurt during the study. All captures and manipulation followed ethical standards and were approved by the Direction Régionale de l'Environnement, de l'Aménagement et du Logement (Hérault). Stomach contents were stored individually in ethanol. A total of 1062 stomach contents (736 individuals) was sampled: 271 in April, 235 in May, 266 in June, and 290 in July (Supplementary Material Table S1). All manipulations were conducted at each study site to avoid displacement of individuals.

The occurrence of native Mediterranean tree frogs (Hyla meridionalis) and palmate newts (Lissotriton helveticus) was determined in order to account for their period of residency in water and to estimate the period during which they might be vulnerable to marsh frogs in the 21 studied ponds. This study focused on these two native species because they spend long periods in ponds during the sampling period and because they are potential prey present mainly at the water surface (tree frogs) and in the water (palmate newts). The number of adult marsh frogs was determined every month at each pond by visual counting (using $10 \times 42$ Swarowski binoculars from a distance to the pond and then walking slowly around the pond) and used as an index of abundance. Preliminary research showed that visual counting is proportional and close to the number of individuals present 
simultaneously at each site as estimated by capture-mark-recapture experiments $\left(R^{2}=0.73\right.$, $p<0.001, n=14$, F. Pille \& M. Denoël, unpublished data), therefore providing an estimate of potential pressure at each visit.

Amphibian prey items were identified under a stereoscopic microscope (Zeiss Stemi 2000). They were identified at the species level and developmental stage when their state of digestion allowed (i.e., post-metamorphic versus larval [54]). The SVL of amphibians preyed upon by marsh frogs was measured using a morphometric measurement tool on stomach-content pictures (TPSdig2 software; [55]). Amphibians ingested by marsh frogs were then classified according to three categories: metamorphosed anurans, tadpoles, and newts. Adults and larvae of newts were considered to belong to the same category because of their low occurrence in stomach contents and their similar habitat preferences.

\subsection{Statistical Analyses}

Using general linear mixed models (GLMM) with a binomial distribution, the potential effects of two variables were tested on the presence of each type of prey (metamorphosed anurans, tadpoles, newts; $0=$ absence of prey, $1=$ presence of prey) in the stomachs of marsh frogs: SVL of marsh frogs (continuous variable, in $\mathrm{mm}$, ln transformed values) and time (month, from April to July). Because newts and tadpoles were found in all ponds and thus were available for predation by marsh frogs, GLMMs included the 21 ponds for these two groups of amphibians. However, according to visual detection, native metamorphosed anuran species predated by invasive marsh frogs occurred in only 15 ponds. Thus, GLMMs assessing predation occurrence on metamorphosed anurans were performed on this reduced dataset. Individuals and ponds were considered nested random factors. Akaike information criterium (AIC) and AIC weights were calculated to rank each candidate model [56]. All possible combinations of factors were tested using automated selections. The most parsimonious models with the lowest AIC were considered to be the best models (i.e., models with $\triangle \mathrm{AIC}<2$ were considered equal models). Averaging of these models $(\triangle \mathrm{AIC}<2)$, which computes the weighted means of the parameter estimates, was performed. The $95 \% \mathrm{CI}$ of estimates of average models were calculated to assess the magnitude of the effects. Differences in SVL between marsh frogs that preyed on native amphibians and those that did not were assessed by computing Cohen's d with confidence intervals (bootstraps, $n=10,000$ repetitions). An effect was considered important when the $95 \% \mathrm{CI}$ did not include zero [57]. The relationship between the SVL of preyed-upon amphibians and the SVL of marsh frogs (ln transformed values for both SVL to reach normal distributions) was assessed using a linear model. Confidence intervals of means presented in the results were calculated using bootstraps ( $n=10,000$ repetitions). All analyses were performed in R 3.6.1 using the lme4 and MuMIn packages [58,59].

Numbers of adult Mediterranean tree frogs and adult palmate newts that could have been consumed by marsh frogs during the whole study period were estimated from the stomach samples. The analysis focused on these two species because they were the only two ubiquitous native amphibians at the study sites. Two scenarios were tested: (1) a conservative scenario, which limits overestimation of predation pressure by considering previously estimated gastric-evacuation times for frogs [60] and which includes only fresh prey in calculation (i.e., consumed within the day), but that ignores the occurrence of more digested prey and may therefore underestimate predation rates; (2) a non-conservative scenario, for which estimates were computed based on the total number of consumed adults, whether recently ingested or in an advanced stage of digestion, but which can therefore overestimate predation, as some prey might have been ingested one day earlier. In both scenarios, estimates of predation pressure were computed for each month for which prey were found in the ponds by extrapolating the number of prey items observed in stomach contents to the maximum number of counted marsh frogs per visit during each month. These values were multiplied by the number of days per month to obtain the monthly estimated number of consumed individuals, and each estimation was divided 
by the number of ponds in which each species was observed (Mediterranean tree frogs: $n=15$ ponds; palmate newts: $n=21$ ponds).

\section{Results}

\subsection{Consumed Amphibians}

From all samples (April-July), amphibians were found in 96 out of 1062 predator stomachs (i.e., $9.04 \%$ of samples); $6.02 \%$ of the marsh frogs had preyed on anurans (metamorphosed anurans: $1.31 \%$; tadpoles: $4.8 \%$ ), $2.25 \%$ on newts (adults: $0.94 \%$; larvae: $1.12 \%$; undetermined: $0.28 \%$ ), and $1.31 \%$ on undetermined amphibian remains. Marsh frogs consumed all native amphibian species known in Larzac Plateau either at the larval stage (anurans: Bufo spinosus, Epidalea calamita, Pelobates cultripes, Alytes obstetricans; caudates: L. helveticus, Triturus marmoratus) or the post-metamorphic stage (anurans: H. meridionalis, Pelodytes punctatus; caudates: L. helveticus; Figure 1; Supplementary Material Table S2). A single paedomorphic $L$. helveticus (i.e., a gilled adult) was identified in the stomach contents. Metamorphosed anurans, tadpoles, and newts represented, respectively, 8.46\%, 73.54\%, and $17.98 \%$ of the relative abundance of amphibians preyed upon by marsh frogs $(0.02 \%$ non-determined). Cannibalism occurred in a very small proportion of captured marsh frogs and included predation on both juveniles $(0.09 \%)$ and tadpoles $(0.47 \%)$. Predation on amphibians occurred in 20 of the 21 sites.

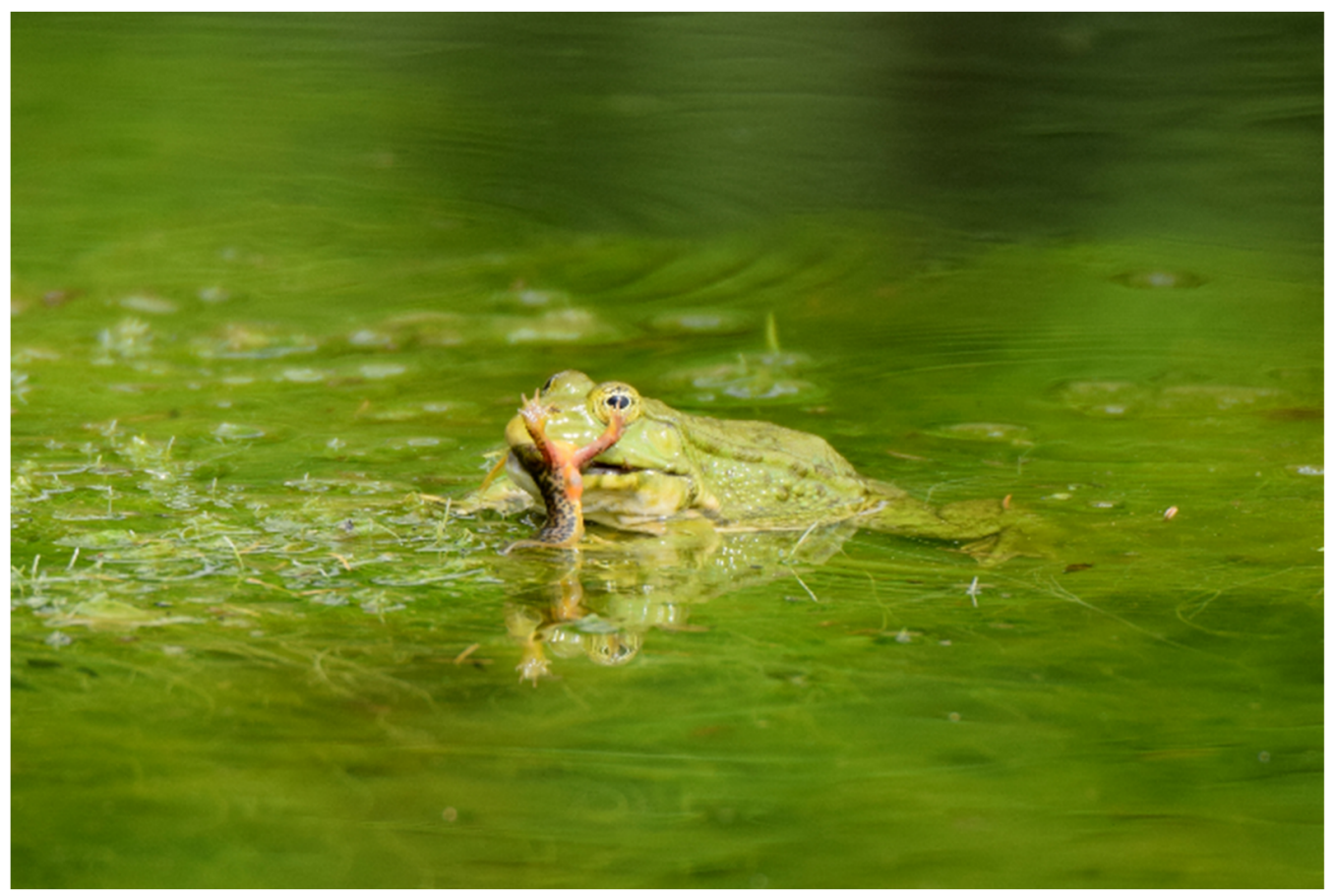

Figure 1. Marsh frog (Pelophylax ridibundus) preying on an adult palmate newt (Lissotriton helveticus) in a pond of the Larzac Plateau. Photography by V. Renard.

\subsection{Temporal Variations}

Model selection on the different GLMMs showed that time (i.e., months) was a good predictor (proportion decreasing through months) of the occurrence of anurans in waterfrog stomachs. This parameter was selected in the model with the lowest AIC for the metamorphosed anurans, but it did not have a strong effect according to the model averaging performed on the two best models $(\triangle \mathrm{AIC} \leq 2$; Table 1$)$. In tadpoles, it was selected in the two best models used in model averaging $(\triangle \mathrm{AIC} \leq 2$; Table 1$)$. Model averaging confirmed a negative effect of the time predictor in tadpoles (estimate $=-0.68,95 \%$ CI: -1.006 to -0.371; Figure 2, Supplementary Material Table S3) and suggested a similar but weak tendency in metamorphosed anurans (estimate $=-0.34,95 \%$ CI: -1.018 to 0.323 ; Figure 2, 
Supplementary Material Table S3). This is explained by a decrease in the frequency of occurrence of metamorphosed anurans and tadpoles in the stomachs of marsh frogs between April and July (Figure 3). The effect of time was not strong for newt occurrence (Figure 2), being selected in only one of the three best models $(\triangle \mathrm{AIC} \leq 2)$.

Table 1. Comparison of models explaining the occurrence of amphibians in stomach contents. Models (all shown) are ranked from the best to the worst according to AIC. Explanatory parameters were time (i.e., months) and SVL (snout-vent length) of marsh frogs.

\begin{tabular}{|c|c|c|c|c|c|c|}
\hline Variable & Rank & Time & SVL & AIC & $\Delta \mathrm{AIC}$ & Weight \\
\hline \multirow{5}{*}{$\begin{array}{l}\text { Metamorphosed } \\
\text { anuran occurrence }\end{array}$} & 1 & -0.514 & 8.213 & 124.9 & 0.00 & 0.677 \\
\hline & 2 & & 8.752 & 126.4 & 1.50 & 0.323 \\
\hline & 3 & -0.759 & & 138.6 & 13.70 & 0.001 \\
\hline & 4 & & & 145.2 & 20.30 & 0.000 \\
\hline & $\begin{array}{l}\text { Parameter } \\
\text { importance }\end{array}$ & 0.678 & 0.678 & & & \\
\hline \multirow{5}{*}{$\begin{array}{c}\text { Tadpole } \\
\text { occurrence }\end{array}$} & 1 & -0.684 & & 351.0 & 0.00 & 0.708 \\
\hline & 2 & -0.699 & -0.441 & 352.8 & 1.80 & 0.292 \\
\hline & 3 & & & 371.3 & 20.30 & 0.000 \\
\hline & 4 & & 0.664 & 372.8 & 21.80 & 0.000 \\
\hline & $\begin{array}{l}\text { Parameter } \\
\text { importance }\end{array}$ & $>0.999$ & 0.292 & & & \\
\hline \multirow{5}{*}{ Newt occurrence } & 1 & & & 131.1 & 0.00 & 0.449 \\
\hline & 2 & & 5.081 & 132.0 & 0.90 & 0.279 \\
\hline & 3 & -0.109 & & 133.0 & 1.90 & 0.168 \\
\hline & 4 & -0.107 & 5.121 & 134.0 & 2.90 & 0.104 \\
\hline & $\begin{array}{l}\text { Parameter } \\
\text { importance }\end{array}$ & 0.272 & 0.383 & & & \\
\hline
\end{tabular}

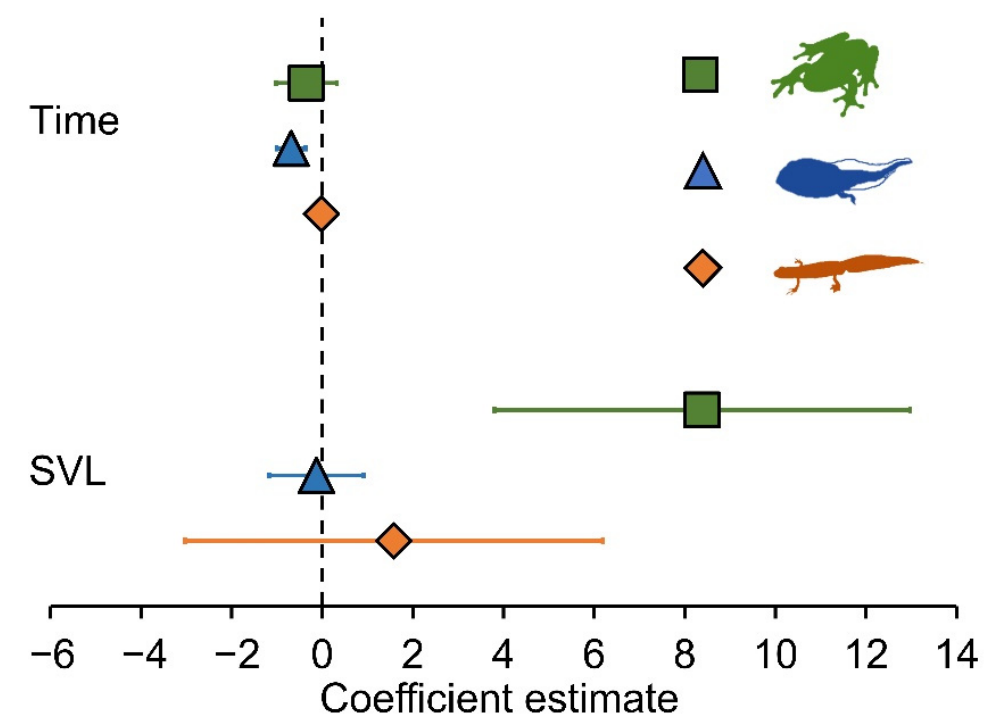

Figure 2. Effect of parameters in average GLMM models assessing amphibian occurrence in stomach contents of marsh frogs (estimates, 95\% CI). Green lines and squares: metamorphosed anurans; blue lines and triangles: tadpoles; orange lines and diamonds: newts. Time: months (April to July); SVL (snout-vent length): body size of marsh frogs. 


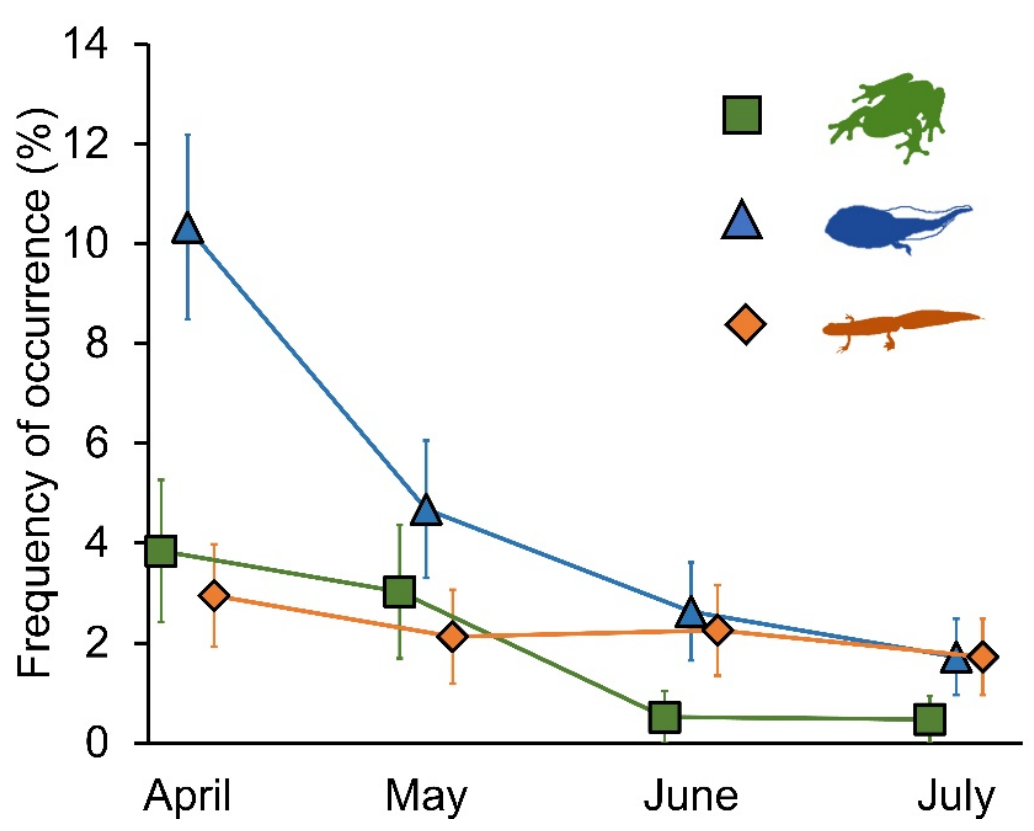

Figure 3. Monthly frequency of occurrence of amphibians in stomach contents of marsh frogs $(n=1062)$. Green lines and squares: metamorphosed anurans; blue lines and triangles: tadpoles; orange lines and diamonds: newts. Whiskers: SE.

\subsection{Body Size}

The effect of the body size of marsh frogs (SVL) on the consumption of metamorphosed anurans was retained in the two best models $(\triangle \mathrm{AIC} \leq 2$; Table 1$)$. Indeed, marsh frogs that consumed metamorphosed anurans were larger than those that did not prey on these organisms (Cohen's d $=1.14,95 \% \mathrm{CI}=0.81$ to 1.49; Figure 4). Model averaging confirmed this very strong effect (zero excluded from CI; estimate $=8.38,95 \%$ CI: 3.802 to 12.971 ; Figures 2 and 4$)$. SVL was selected in only one of the three best models $(\triangle \mathrm{AIC} \leq 2)$ used for model averaging in newts and did not show any effect, as highlighted by the confidence intervals crossing zero (estimate $=1.58,95 \%$ CI: -3.029 to 6.192; Figure 2). For tadpole consumption, SVL was selected in one of the two best models ( $\triangle$ AIC $\leq 2)$; model averaging did not confirm this effect (estimate $=-0.12,95 \%$ CI: -1.170 to 0.912 ; Table 1 , Figure 2 ). Marsh frogs that consumed tadpoles and newts were larger than individuals that did not (respectively, Cohen's d $=0.29,95 \% \mathrm{CI}=0.03$ to 0.55 and Cohen's $\mathrm{d}=0.50,95 \% \mathrm{CI}=0.08$ to 0.89; Figure 4). Linear regression showed a positive relationship between the SVL of preyed-upon amphibians (metamorphosed anurans, tadpoles, and newts combined) and the SVL of marsh frogs $\left(R^{2}=0.35\right.$; slope estimate $=1.68,95 \%$ CI: $1.13-2.22$; Figure 5).

\subsection{Predation Pressure}

Among the 21 ponds that were surveyed for four months, Mediterranean tree frogs were observed in 15 ponds and palmate newts in all ponds. Across all ponds, the total numbers of adult marsh frogs observed by visual counting over the four-month period from April to July were 289, 445, 521, and 535, respectively (Supplementary Material Table S4). Following the conservative scenario (i.e., considering only fresh prey from the stomach contents of marsh frogs) and the time period of coexistence between marsh frogs and the native species (Supplementary Material Table S4), a minimum global consumption of 96 adult Mediterranean tree frogs and 496 adult palmate newts was estimated in the studied ponds over the study period. Per pond, this translates to, on average, estimates of 6.4 and 23.6 individuals, respectively. The non-conservative scenario (i.e., considering all consumed adults, whatever the state of digestion) provided higher estimations of predation rates, with a maximum global consumption of 412 adult Mediterranean tree frogs and 790 adult palmate newts. Predation pressure of invasive marsh frogs at the pond level was highest in 
April for adult Mediterranean tree frogs, ranging from six in April to zero over the following months in the conservative scenario and 12.8, 10.8, 3.9, and 0 for April, May, June, and July, respectively, in the non-conservative scenario (Supplementary Material Figure S2). For palmate newts, the conservative scenario provided estimates of 15.2, 5.6, 2.8, and 0 for April, May, June, and July, respectively. The non-conservative scenario estimated predation pressure of 15.2, 5.6, 16.8, and 0 over the same period (Supplementary Material Table S4).

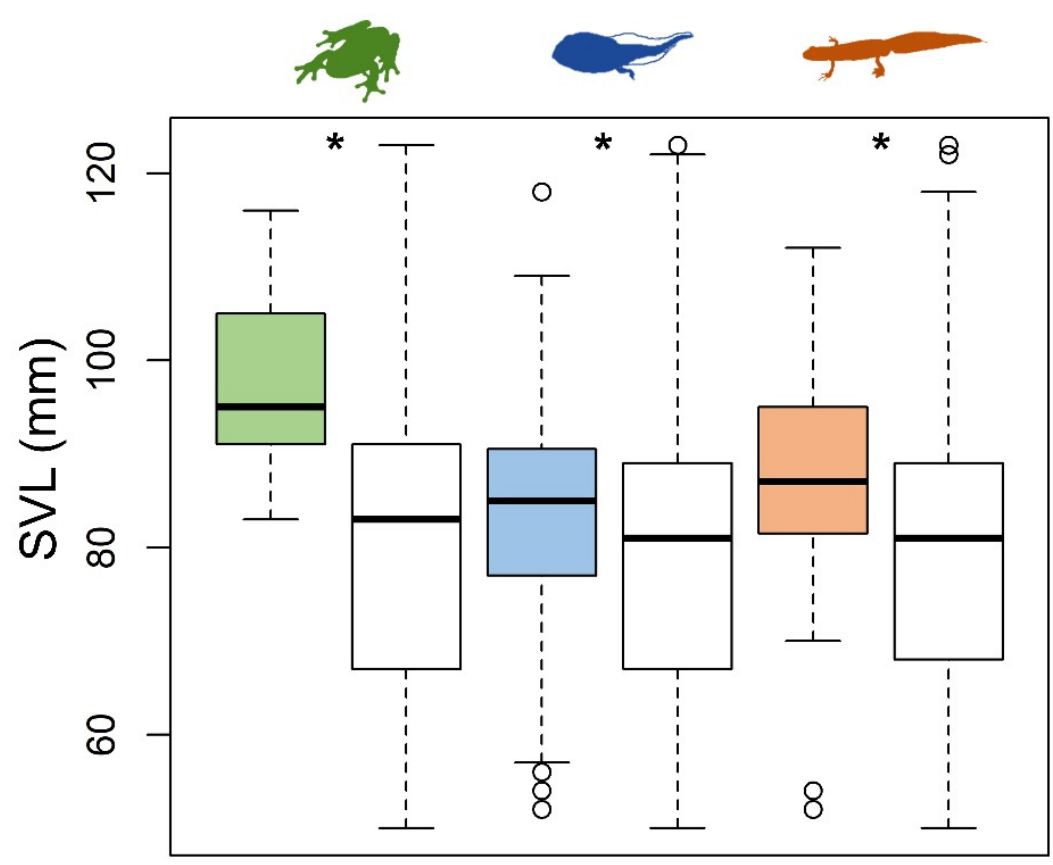

Figure 4. Size (snout-vent length, in $\mathrm{mm}$ ) of marsh frogs that consumed amphibians (colored bars) and those that did not consume amphibians (clear bars). Green (left): metamorphosed anurans; blue (middle): tadpoles; orange (right): newts. Boxplots represent median (25-75\%) \pm 1.5 IQR. Open circles represent outliers. Asterisks indicate significant differences between groups (see text).

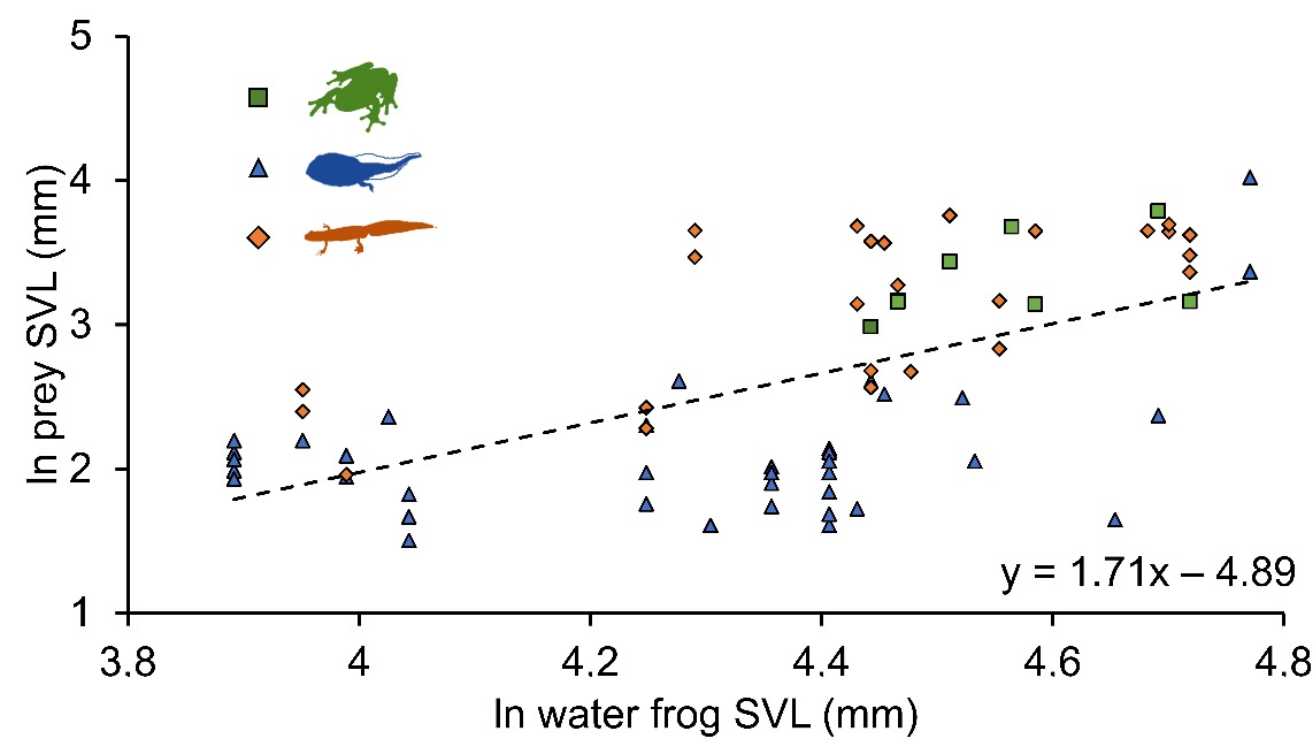

Figure 5. Size-selective predation: Size of consumed amphibians as a function of size of Pelophylax water frog. SVL: snout-vent length. Green squares: metamorphosed anurans; blue triangles: tadpoles; orange diamonds: newts. Dotted line represents the linear regression between the SVL of marsh frogs and the SVL of ingested amphibians $(y=1.71 x-4.89)$. 


\section{Discussion}

The present study provides a quantitative assessment of the consumption of native amphibians by invasive marsh frogs in ponds and highlights the predation pressure on both Mediterranean tree frogs and newts. By encompassing multiple sites over time, these results shed new light on our understanding of the diet of the invaders and show that time and context can mask or exacerbate the observed effects, depending on sampling design. Moreover, these replicated analyses give better insight in terms of global estimates of amphibians predated during a complete active period at ponds. As Pelophylax water frogs are now invading most of western Europe [26-29], our findings have broad implications for the conservation of native amphibians.

\subsection{Predation on Natives}

Most anurans are generalist feeders, foraging on a wide variety of prey [61]. Within an invasion context, this life-history trait suggests that invasive frogs could predate on native amphibians [62]. In the present study, 9\% of the invaders had consumed amphibians, suggesting opportunistic predation rather than trophic specialization. This predation rate appeared to be higher than in other invasive frogs, for which native amphibian consumption is typically low, such as in Cuban treefrogs [63], African clawed frogs [22], or cane toads [16]. Our results show predation rates similar to the ranges reported in invasive bullfrogs $(4-32 \%)[18,19,21]$. Despite having a larger gape width than marsh frogs, bullfrogs, which belong to the same family (Ranidae), share biological traits with them and are known to have strong impacts on native amphibian populations, mainly through predation [20]. On the other hand, our results show higher predation rates on native amphibians by $P$. ridibundus water frogs from the invaded range than previously shown from other stomach-content-based studies carried out in the native range (Table 2). Indeed, in most of these studies, no native amphibians were predated by native marsh frogs [33-38,64-68], whereas in a few others, frequency of predation on heterospecific amphibians ranked between 0.10 and $4.61 \%$ [39-42]. These differences might be due to differences in the sampled habitats and the study design. Indeed, our study focused on a large set of ponds in an area where native amphibians are widespread and diversified, whereas previous studies in the native range included lakes, rivers, and ponds where co-occurrence patterns were not shown.

In the present study, all eight native amphibian species were preyed upon by marsh frogs. Two of the species that were preyed upon have a high-risk conservation status; the spadefoot toad P. cultripes is considered high-priority at the regional and national scale $[48,69]$, and T. marmoratus is also considered to be in decline according to the regional IUCN red list [48]. Although less threatened, even common species, such as palmate newts, were shown declining in large parts of their range, including in Larzac [70]. Therefore, predation pressure from invasive water frogs, such as marsh frogs, may act as a new stressor, possibly contributing to the current declines (see Section 4.6 for impact assessment).

Whether this predation rate is facilitated by some form of naïveté of native populations is unknown. Indeed, native amphibians that did not co-evolve with their new, exotic predators may lack anti-predator mechanisms [11]. In Larzac, and more broadly in southern France, there were indeed no $P$. ridibundus naturally present, but phylogenetically related species of Pelophylax exist in other parts of the range of the native species [26]. The naïveté is therefore possibly less marked than that relating to the continental translocation of the other species of invaders listed hereabove. 


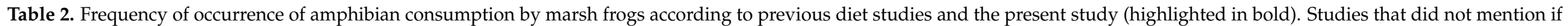
consumed amphibians were linked to cannibalism or predation on heterospecifics were not included.

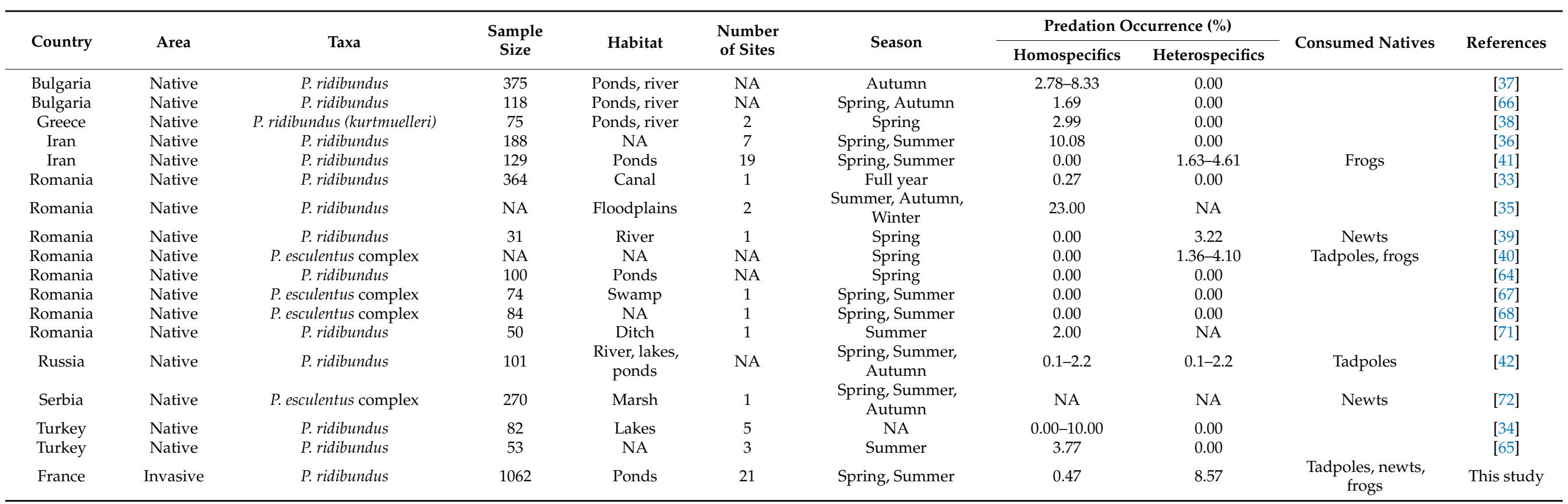




\subsection{Predation on Larval and Metamorphosed Life Stages}

Every life stage of the native amphibians in our study (except eggs) was impacted by predation by marsh frogs. Mediterranean tree frogs and palmate newts were the mostpreyed-upon amphibians at the post-metamorphic adult stage. These predation events indicate that marsh frogs forage on organisms that have different microhabitat/spaceuse habits. Indeed, palmate newts are entirely aquatic and specifically benthic in ponds, except when moving up to breathe, whereas treefrogs spend most of their time at the water/air interface when present at ponds ([48]; M. Denoël \& F. Pille, personal observation). Additionally, most native anurans were found in stomach contents exclusively at the larval stage. This also indicates predation on fully aquatic amphibians, which exploit different parts of the ponds, such as the bottom and the water column. Preliminary observations show that marsh frogs can ingest them from the water-air interface in the middle of ponds, but it is also possible that marsh frogs chase their prey during underwater movements as well. Detailed quantitative behavioral observations are needed to determine the predatory strategies of marsh frogs and therefore in which microhabitat they forage, particularly on amphibians.

\subsection{Phenology of Predation}

Time was the main determinant of native-anuran consumption by marsh frogs. This underlines the importance of conducting studies across a broad range of the active period of amphibians to assess predation by invasive alien species, as was done here. Indeed, by focusing on shorter surveys, predation by invasive frogs could have been overlooked, therefore leading to misleading conclusions regarding the conservation of impacted native species. In this study, predation on anurans (tadpoles and metamorphosed anurans) occurred mainly in April, suggesting a strong effect of the abundance of native species related to phenology. Because water frogs spend a great deal of time in ponds (i.e., in spring and summer), they can interfere with any crucial period in the phenology of native amphibians. For the Mediterranean tree frog, predation by marsh frogs occurred almost exclusively in April and included gravid females. This indicates that predation mostly occurred during the main period of reproductive activity at the study sites, when breeding adults reached high abundances in ponds. Furthermore, some other anuran species, such as Bufo spinosus, lay eggs at the very end of winter, resulting in high numbers of small tadpoles in ponds in April [48]. For Pelodytes punctatus and Alytes obstetricans, some tadpoles remain at the larval stage during winter and thus occur in ponds in early spring [48]. Therefore, as a result of their phenology, all these native amphibians are available as prey for marsh frogs at the beginning of spring. This is especially the case for tadpoles, which are highly abundant in ponds during spring and then metamorphose before summer.

Thus, patterns of phenology are more likely to be a reflection of the availability of native amphibians rather than a change in the behavior of marsh frogs.

By contrast, despite their higher numbers in early spring, newts can remain underwater in summer at the study sites [73], making them potential prey for marsh frogs during the overall survey period. However, although the present results fit well with the phenology of the preyed-upon amphibians, future research should investigate how additional factors may also explain the temporal variation of amphibian consumption.

\subsection{Size-Selective Predation}

Most trophic interactions are governed by size-selective predation (i.e., the fact that predators are gape-size-limited) [74]. In a recent review, Measey et al. [62] showed that the size of predatory frog species was a dominant predictor of anurophagy. Our results demonstrate that in marsh frogs, this pattern also occurs at the intraspecific level. This effect was particularly strong for metamorphosed anurans, which are large prey only consumed by the largest marsh frogs. The stomach contents of large marsh frogs included both small and large prey items. This is consistent with the general observation that larger 
predators, while able to catch large prey, continue to prey on smaller prey organisms [74]. In marsh frogs, this general trend is reflected by the fact that smaller individuals can prey upon tadpoles and small newts (e.g., larvae), whereas larger individuals consume a broader spectrum of amphibian prey ranging from adult native anurans and newts to anuran and newt larvae. In terms of conservation, predation on adult amphibians only by the largest marsh frogs shows that they are the most problematic for populations. This is reinforced by the fact that water frogs, such as marsh frogs (mean SVL: $80 \mathrm{~mm}$; this study) and other invasive ranids (bullfrog mean SVL: $143 \mathrm{~mm}$ [21] and $110 \mathrm{~mm}$ [23]), can reach larger sizes than most natives (e.g., Mediterranean tree frogs SVL: $45 \mathrm{~mm}$, this study).

\subsection{Environmental Context}

The structure of habitats influences the composition of amphibian species and their abundance in ponds [75]. Because frogs are generalist predators, this variability may influence diet composition. For instance, habitat influences the predation patterns of invasive bullfrogs [21]. In Larzac, ponds can be heterogeneous according to environmental parameters such as size, depth, vegetation composition, and cover. To test for the influence of these various parameters on the predation rates of invasive marsh frogs turns out to be a difficult task in a field study. Indeed, without knowing the precise availability of each type of prey following gradients of habitat heterogeneity, it is not possible to clearly identify site-specific strategies of frogs. However, by including a large number of replicated sites (21 ponds), this study encompasses habitat heterogeneity and provides insights about global predation patterns across pond networks, with predation on amphibians found in almost all studied ponds. Furthermore, despite possible differences in the composition of amphibian species across ponds, the most abundant and ubiquitous prey (i.e., H. meridionalis and L. helveticus) were present in the majority of ponds (15 and 21, respectively), making them available prey for marsh frogs. These two species were predated in at least four and eight ponds, respectively (i.e., in at least $26.6 \%$ and $38 \%$ of the studied ponds). However, more finescale study is needed to better understand how pond complexity could impact predatory strategies [21,38], though this would also require behavioral observations.

\subsection{Predation Pressure and Conservation Concerns}

Consumption by invasive predators is considered a direct impact on native species because it involves the death of individuals. Thus, predation could contribute to population decline by directly increasing mortality rates, leading to the removal of native species in the worst cases [76]. Although the present study did not measure native amphibian population dynamics and therefore potential decline patterns, the results show that metamorphosed native amphibians, especially Mediterranean tree frogs and palmate newts, were preyed upon by invasive marsh frogs in several surveys and ponds. An occurrence of $9 \%$ of heterospecific amphibians may seem low at first sight, but such a rate must be contextualized with the number of invasive frogs present in the ponds and the period in which prey and predators co-occur. As large numbers of marsh frogs were present in the studied ponds over a long period, predation pressure was estimated to reach hundreds of predated metamorphosed individuals over an active season in the studied ponds. This suggests that predation by invasive water frogs may be deleterious for native populations of Mediterranean tree frogs and may also affect those of palmate newts. Both scenarios, even the most conservative, which considers only fresh prey for estimations, give estimates of high numbers of consumed individuals. Because of the difference in data selection used for each scenario (i.e., fresh prey versus all prey), they may be considered "optimistic" and "pessimistic" points of view, respectively. The predations occurring during the breeding period is particularly critical because reproduction may be altered, and native females may be predated before laying their eggs. On the other hand, our results highlight a neglected long-term aspect of predation: that even if amphibians were found only in the stomach contents of some of the studied invaders, the fact that these invaders remain continuously in ponds for months increases their predation rate on a full-year basis. However, further 
studies focusing on densities of native newts and tree frogs across time are needed to precisely describe the impacts of invasive water frogs.

Our results show some predation pressure against the two targeted native amphibians 10-20 years after the start of the biological invasion in the study area (M. Denoël, personal observation). Considering this time lapse, one likely hypothesis is that predation pressures might have been higher at an earlier stage of the invasion because of possible prey naiveté or higher densities of available native amphibians. Unfortunately, there are currently no long-term quantitative datasets of population changes of native amphibians in association with the invasion of water frogs. Despite this, qualitative observations suggest that tree frogs were once more commonly seen in Larzac ponds than they are today. In some of these ponds, it has become exceptional to find tree frogs now that they have been invaded by marsh frogs (M. Denoël, personal observation). Future studies should therefore focus on such temporal patterns of changes in local communities. From this perspective, the present results provide indication for a plausible detrimental direct consumptive effect of water frogs, the global consequences of which remain to be determined. However, it is becoming difficult, as marsh frogs have already invaded most ponds in the area. Furthermore, predation from invasive herpetofauna may lead to various impacts on native species, such as changes in behavior, spatial ecology, or defense mechanisms [4]. These non-consumptive effects may have a strong influence $[12,77]$ and should be considered in addition to the consumptive effects shown in this study.

\section{Conclusions}

Although Pelophylax water frogs were previously considered a threat mainly because of the risk of genetic pollution of related taxa (see e.g., [27]), the present study on marsh frogs shows another risk in pond environments: direct predation. Specifically, through a detailed account over time and across multiple water bodies, this study provides evidence for the overall ecological threat posed by invasive water frogs. By predating upon all local species, including both caudates and anurans at different life-history stages, marsh frogs interact negatively with all components of native amphibian communities. Because invasive alien Pelophylax water frogs are now well established in large geographic areas across western Europe, we argue that these invasive alien predators may have a negative impact on native amphibian populations similar to that found in other invasive taxa $[78,79]$. Because the global impact of invaders is likely complex [9,11], future fine-scale research is needed to understand the long-term consequences of invasions and how invaded communities change with time and pressures from invaders.

Supplementary Materials: The following are available online at https://www.mdpi.com/article/ 10.3390/d13110595/s1: Figure S1: Sampling area of invasive marsh frogs in Larzac. Background indicates relief with lowest elevation in dark. The insert shows France and three departments (Hérault, Gard, Aveyron). Detailed coordinates are not given for conservation purposes. Figure S2: Mean observed abundance of native Mediterranean tree frogs in the 15 ponds where they were observed (visual counting). Whiskers: 95\% CI. Table S1: Sample size of studied marsh frogs per pond and per month. Table S2: Total number $(\mathrm{N})$, number of occurrence $(\mathrm{O})$, and frequency of occurrence (FO) of amphibian prey types in stomach of marsh frogs. ND: not determined. Table S3: Results of model averaging of the GLMM models showing factors influencing amphibian occurrence in stomach contents of marsh frogs. MA: metamorphosed anuran. Table S4: Estimated numbers of adult Mediterranean tree frogs (Hyla meridionalis) and adult palmate newts (Lissotriton helveticus) preyed by marsh frogs (MF) during the whole study period according to a conservative scenario (intact fresh prey items only) and to a non-conservative scenario (all consumed amphibians).

Author Contributions: Conceptualization, F.P. and M.D.; methodology, M.D.; validation, M.D.; formal analysis, F.P. and M.D.; investigation, F.P., M.D. and L.P.; resources, M.D.; data curation, F.P. and L.P.; writing — original draft preparation, F.P.; writing—review and editing, M.D.; visualization, F.P.; supervision, M.D.; project administration, M.D.; funding acquisition, M.D. All authors have read and agreed to the published version of the manuscript. 
Funding: This research was supported by PDR grant number T.0070.19 of the Fonds de la Recherche Scientifique-FNRS.

Institutional Review Board Statement: Capture and manipulations were carried out under permit from Direction Régionale de l'Environnement, de l'Aménagement et du Logement (Hérault).

Informed Consent Statement: Not applicable.

Data Availability Statement: Data are available from the authors upon reasonable request.

Acknowledgments: We thank C. Duret, L. Lorrain, B. Lejeune, P. Levionnois, L. Seger, P. Padilla, A. Berna for their help in the field, V. Renard for permission to use her photograph taken during fieldwork, A. Lacombe for her help with statistical analysis, the landowners and municipalities for allowing access to their ponds, and the Institut Géographique National for providing maps through the INSPIRE program. M. Denoël is a Research Director of the Fonds de la Recherche Scientifique-FNRS.

Conflicts of Interest: The authors declare that they have no conflict of interest.

\section{References}

1. Strayer, D.L. Alien species in fresh waters: Ecological effects, interactions with other stressors, and prospects for the future. Freshw. Biol. 2010, 55, 152-174. [CrossRef]

2. Gallardo, B.; Clavero, M.; Sánchez, M.I.; Vilà, M. Global ecological impacts of invasive species in aquatic ecosystems. Glob. Chang. Biol. 2016, 22, 151-163. [CrossRef]

3. Kats, L.B.; Ferrer, R.P. Alien predators and amphibian declines: Review of two decades of science and the transition to conservation. Divers. Distrib. 2003, 9, 99-110. [CrossRef]

4. Kraus, F. Impacts from invasive reptiles and amphibians. Annu. Rev. Ecol. Evol. 2015, 46, 75-97. [CrossRef]

5. Sih, A.; Bolnick, D.I.; Luttbeg, B.; Orrock, J.L.; Peacor, S.D.; Pintor, L.M.; Preisser, E.; Rehage, S.; Vonesh, J.R. Predator-prey naïveté, antipredator behavior, and the ecology of predator invasions. Oikos 2010, 119, 610-621. [CrossRef]

6. Park, K. Assessment and management of invasive alien predators. Ecol. Soc. 2004, 9, 12. [CrossRef]

7. Salo, P.; Korpimäki, E.; Banks, P.B.; Nordström, M.; Dickman, C.R. Alien predators are more dangerous than native predators to prey populations. Proc. R. Soc. B 2007, 274, 1237-1243. [CrossRef]

8. Castaldelli, G.; Pluchinotta, A.; Milardi, M.; Lanzoni, M.; Giari, L.; Rossi, R.; Fano, E.A. Introduction of exotic fish species and decline of native species in the lower Po basin, north-eastern Italy. Aquat. Conserv. Mar. Freshw. Ecosyst. 2013, $23,405-417$. [CrossRef]

9. Falaschi, M.; Melotto, A.; Manenti, R.; Ficetola, G.F. Invasive species and amphibian conservation. Herpetologica 2020, 76, $216-227$. [CrossRef]

10. Beebee, T.J.C.; Griffiths, R.A. The amphibian decline crisis: A watershed for conservation biology? Biol. Conserv. 2005, 125, 271-285. [CrossRef]

11. Nunes, A.L.; Fill, J.M.; Davies, S.J.; Louw, M.; Rebelo, A.D.; Thorp, C.J.; Vimercati, G.; Measey, J. A global meta-analysis of the ecological impacts of alien species on native amphibians. Proc. R. Soc. B 2019, 286, 20182528. [CrossRef]

12. Bucciarelli, G.M.; Blaustein, A.R.; Garcia, T.S.; Kats, L.B. Invasion complexities: The diverse impacts of nonnative species on amphibians. Copeia 2014, 4, 611-632. [CrossRef]

13. Lever, C. Naturalized Reptiles and Amphibians of the World; Oxford University Press: Oxford, UK, 2003.

14. Pitt, W.C.; Vice, D.S.; Pitzler, M.E. Challenges of invasive reptiles and amphibians. In Proceedings of the 11th Wildlife Damage Management Conference; Wildlife Damage Management: Fort Collins, CO, USA, 2005; pp. 112-119.

15. Shine, R. The ecological impact of invasive cane toads (Bufo marinus) in Australia. Q. Rev. Biol. 2010, 85, 253-291. [CrossRef]

16. Shine, R. A review of ecological interactions between native frogs and invasive cane toads in Australia. Austral Ecol. 2014, 39, 1-16. [CrossRef]

17. Bissattini, A.M.; Buono, V.; Vignoli, L. Disentangling the trophic interactions between American bullfrogs and native anurans: Complications resulting from post-metamorphic ontogenetic niche shifts. Aquat. Conserv. Mar. Freshw. Ecosyst. 2019, $29,270-281$. [CrossRef]

18. Boelter, R.A.; Kaefer, I.L.; Both, C.; Cechin, S. Invasive bullfrogs as predators in a Neotropical assemblage: What frog species do they eat? Anim. Biol. 2012, 62, 397-408. [CrossRef]

19. Jancowski, K.; Orchard, S. Stomach contents from invasive American bullfrogs Rana catesbeiana (=Lithobates catesbeianus) on southern Vancouver Island, British Columbia, Canada. NeoBiota 2013, 16, 17-37. [CrossRef]

20. Oda, F.H.; Guerra, V.; Grou, E.; de Lima, L.D.; Proença, H.C.; Gambale, P.G.; Takemoto, R.M.; Teixeira, C.P.; Campiao, K.M.; Ortega, J.C.G. Native anuran species as prey of invasive American bullfrog Lithobates catesbeianus in Brazil: A review with new predation records. Amphib. Reptile Conserv. 2019, 13, 217-226.

21. Silva, E.T.; Da Filho, O.P.R.; Feio, R.N. Predation of native anurans by invasive Bullfrogs in Southeastern Brazil: Spatial variation and effect of microhabitat use by prey. S. Am. J. Herpetol. 2011, 6, 1-10. [CrossRef] 
22. Courant, J.; Vogt, S.; Marques, R.; Measey, J.; Secondi, J.; Rebelo, R.; De Villiers, A.; Ihlow, F.; De Busschere, C.; Backeljau, T. Are invasive populations characterized by a broader diet than native populations? PeerJ 2017, 5, e3250. [CrossRef]

23. Wu, A.Z.; Li, Y.; Wang, Y.; Adams, M.J. Diet of introduced bullfrogs Rana catesbeiana: Predation on and diet overlap with native frogs on Daishan Island, China. J. Herpetol. 2005, 39, 668-674. [CrossRef]

24. Measey, G.J.; Vimercati, G.; De Villiers, F.A.; Mokhatla, M.M.; Davies, S.J.; Thorp, C.J.; Rebelo, A.D.; Kumschick, S. A global assessment of alien amphibian impacts in a formal framework. Divers. Distrib. 2016, 22, 970-981. [CrossRef]

25. Dufresnes, C.; Leuenberger, J.; Amrhein, V.; Bühler, C.; Thiébaud, G.; Bohnenstengel, T.; Dubey, S. Invasion genetics of marsh frogs (Pelophylax ridibundus sensu lato) in Switzerland. Biol. J. Linn. Soc. 2018, 123, 402-410. [CrossRef]

26. Dufresnes, C.; Denoël, M.; Di Santo, L.; Dubey, S. Multiple uprising invasions of Pelophylax water frogs, potentially inducing a new hybridogenetic complex. Sci. Rep. 2017, 7, 6506. [CrossRef]

27. Dufresnes, C.; Di Santo, L.; Leuenberger, J.; Schuerch, J.; Mazepa, G.; Grandjean, N.; Canestrelli, D.; Perrin, N.; Dubey, S. Cryptic invasion of Italian pool frogs (Pelophylax bergeri) across Western Europe unraveled by multilocus phylogeography. Biol. Invasions 2017, 19, 1407-1420. [CrossRef]

28. Ficetola, G.F.; Scali, S. Invasive amphibians and reptiles in Italy. Atti. VIII Congr. Naz. Soc. Herpetol. Ital. 2010, 335-340.

29. Holsbeek, G.; Mergeay, J.; Volckaert, F.A.M.; De Meester, L. Genetic detection of multiple exotic water frog species in Belgium illustrates the need for monitoring and immediate action. Biol. Invasions 2010, 12, 1459-1463. [CrossRef]

30. Pagano, A.; Crochet, P.A.; Graf, J.D.; Joly, P.; Lodé, T. Distribution and habitat use of water frog hybrid complexes in France. Glob. Ecol. Biogeogr. 2001, 10, 433-441. [CrossRef]

31. Dufresnes, C.; Dubey, S. Invasion genomics supports an old hybrid swarm of pool frogs in Western Europe. Biol. Invasions 2020, 22, 205-210. [CrossRef]

32. Vorburger, C.; Reyer, H. A genetic mechanism of species replacement in European waterfrogs? Conserv. Genet. 2003, 4, 141-155. [CrossRef]

33. Bogdan, H.V.; Covaciu-Marcov, S.D.; Cupsa, D.; Cicort-Lucaciu, S.I. Food composition of a Pelophylax ridibundus (Amphibia) population from a thermal habitat in Banat Region (Southwestern Romania). Acta Zool. Bulg. 2012, 64, $253-262$.

34. Çiçek, K.; Mermer, A. Feeding biology of the marsh frog, Rana ridibunda Pallas 1771, (Anura, Ranidae) in Turkey's lake district. North-West. J. Zool. 2006, 2, 57-72.

35. Cogālniceanu, D.; Palmer, M.W.; Ciubuc, C. Feeding in anuran communities on islands in the Danube floodplain. Amphib.-Reptil. 2000, 22, 1-19. [CrossRef]

36. Fathinia, B.; Rastegar-Pouyani, N.; Darvishnia, H.; Shafaeipour, A.; Jaafari, G. On the trophic spectrum of Pelophylax ridibundus (Pallas, 1771) (Amphibia: Anura: Ranidae) in western Iran. Zool. Middle East 2016, 62, 247-254. [CrossRef]

37. Mollov, I. Sex based differences in the trophic niche of Pelophylax ridibundus (Pallas, 1771) (Amphibia: Anura) from Bulgaria. Acta Zool. Bulg. 2008, 60, 277-284.

38. Plitsi, P.; Koumaki, M.; Bei, V.; Pafilis, P.; Polymeni, R.M. Feeding ecology of the Balkan water frog (Pelophylax kurtmuelleri) in Greece with emphasis on habitat effect. North-West. J. Zool. 2016, 12, $292-298$.

39. Balint, N.; Indrei, C.; Racula, I.; Ursut, A. On the diet of the Pelophylax ridibundus (Anura, Ranidae) in Ticleni, Romania. South-West. J. Hortic. Biol. Environ. 2010, 1, 57-66.

40. Nicoara, A.; Nicoara, M.; Bianchini, F. Diet composition during breeding period in populations of Bufo viridis, Pelobates fuscus and Rana esculenta complex from Ciric river's basin (Iasi, Romania). An. Stiintifice Univ "Al.I. Cuza" Iasi Sect. Biol. Anim. 2005, 51, 179-187.

41. Pesarakloo, A.; Rastegar-Pouyani, N.; Rastegar-Pouyani, E.; Najibzadeh, M.; Shakarami, J.; Kami, H.G.; Shayestehfar, A. Feeding biology and food composition in Pelophylax ridibundus (Pallas 1771) in the Iranian plateau. Russ. J. Herpetol. 2017, 24, 91-98. [CrossRef]

42. Ruchin, A.B.; Ryzhov, M.K. On the diet of the marsh frog (Rana ridibunda) in the Sura and Moksha watershed, Mordovia. Adv. Amph. Res. Former Sov. Union 2002, 7, 197-205.

43. Katsiyiannis, P.; Tzoras, E. First record of Pelophylax kurtmuelleri preying on Hyla arborea in Greece. Parnass. Arch. 2020, 8, 17-18.

44. Gabrion, J. La Néoténie Chez Triturus helveticus Raz. Etude Morphofonctionnelle de la Fonction Thyroidienne. Ph.D. Thesis, Université des Sciences et Techniques du Languedoc, Montpellier, France, 1976.

45. Denoël, M. Priority areas of intraspecific diversity: Larzac, a global hotspot for facultative paedomorphosis in amphibians. Anim. Conserv. 2007, 10, 110-116. [CrossRef]

46. Denoël, M.; Lehmann, A. Multi-scale effect of landscape processes and habitat quality on newt abundance: Implications for conservation. Biol. Conserv. 2006, 130, 495-504. [CrossRef]

47. Durand-Tullou, A. Un Milieu de Civilisation Traditionnelle. Le Causse de Blandas. Ph.D. Thesis, Faculté des Lettres et Sciences Humaines de Montpellier, Montpellier, France, 1959.

48. Geniez, P.; Cheylan, M. Les Amphibiens et Reptiles du Languedoc-Roussillon et Régions Limitrophes; Biotope: Mèze, France; Muséum National D'histoire Naturelle: Paris, France, 2012.

49. Dufresnes, C.; Mazepa, G. Hybridogenesis in Water Frogs. eLS 2020, 1, 718-726. [CrossRef]

50. Christy, M.T. The efficacy of using Passive Integrated Transponder (PIT) tags without anaesthetic in free-living frogs. Aust. J. Zool. 1996, 30, 139-142. [CrossRef] 
51. Winandy, L.; Denoël, M. The use of visual and automatized behavioral markers to assess methodologies: A study case on PIT-tagging in the Alpine newt. Behav. Res. Methods 2011, 43, 568-576. [CrossRef]

52. Solé, M.; Beckmann, O.; Pelz, B.; Kwet, A.; Engels, W. Stomach-flushing for diet analysis in anurans: An improved protocol evaluated in a case study in Araucaria forests, southern Brazil. Stud. Neotrop. Fauna Environ. 2005, 40, 23-28. [CrossRef]

53. Joly, P. Le régime alimentaire des amphibiens: Méthodes d'étude. Alytes 1987, 6, 11-17.

54. Nöllert, A.; Nöllert, C. Guide des Amphibiens d'Europe: Biologie, Identification, Répartition; Delachaux et Niestlé: Paris, France, 2003.

55. Rohlf, F.J. tpsDig2, Version 2.31. Stony Brook; Department of Ecology and Evolution, State University of New York: New York, NY, USA, 2007.

56. Burnham, K.P.; Anderson, D.R. Model Selection and Multimodel Inference: A Practical Information-Theoretic Approach; Springer: New York, NY, USA, 2002.

57. Mazerolle, M.J. Improving data analysis in herpetology: Using Akaike's Information Criterion (AIC) to assess the strength of biological hypotheses. Amphib.-Reptil. 2006, 27, 169-180. [CrossRef]

58. Bates, D.; Maechler, M.; Bolker, B.; Walker, S. Fitting Linear Mixed-Effects Models Using lme4. J. Stat. Softw. 2015, 67, 1-48. [CrossRef]

59. Barton, K. MuMIn: Multi-Model Inference. R Package Version 1.43.17. Available online: https: / /CRAN.R-project.org/package= MuMIn (accessed on 18 September 2020).

60. Loman, J. Food, feeding rates and prey-size selection in juvenile and adult frogs, Rana arvalis Nilss. and R. temporaria L. Ekol. Polska 1979, 27, 581-601.

61. Wells, K.D. The Ecology and Behavior of Amphibians; The University of Chicago Press: Chicago, IL, USA, 2007.

62. Measey, G.J.; Vimercati, G.; De Villiers, F.A.; Mokhatla, M.M.; Davies, S.J.; Edwards, S.; Altwegg, R. Frog eat frog: Exploring variables influencing anurophagy. PeerJ 2015, 3, e1204. [CrossRef]

63. Glorioso, B.M.; Waddle, J.H.; Crockett, M.E.; Rice, K.G.; Percival, H.F. Diet of the invasive Cuban Treefrog (Osteopilus septentrionalis) in pine rockland and mangrove habitats in South Florida. Caribb. J. Sci. 2012, 46, 346-355. [CrossRef]

64. Balint, N.; Citrea, L.; Memetea, A.; Jurj, N.; Condure, N. Feeding ecology of the Pelophylax ridibundus (Anura, Ranidae) in Dobromir, Romania. Biharean Biol. 2008, 2, 27-37.

65. Çiçek, K.; Mermer, A. Food composition of the marsh frog, Rana ridibunda Pallas, 1771, in Thrace. Turk. J. Zool. 2007, 31, 83-90.

66. Mollov, I.; Boyadzhiev, P.; Donev, A. Trophic role of the marsh frog Pelophylax ridibundus (Pallas, 1771) (Amphibia, Anura) in the aquatic ecosystems. Bulg. J. Agric. Sci. 2010, 16, 298-306.

67. Sas, I.; Kovács, É.; Covaciu-Marcov, S.D.; Strugariu, A.; Covaci, R.; Ferenţi, S. Food habits of a pool frog Pelophylax lessonae-edible frog Pelophylax kl. esculentus population from North-Western Romania. Biota 2007, 8, 71-78.

68. Sas, I.; Covaciu-Marcov, S.D.; Strugariu, A.; David, A.; Ilea, C. Food habit of Rana (Pelophylax) kl. esculenta females in a new recorded E-system population from a forested habitat in north-western Romania. Turk. J. Zool. 2009, 33, 1-5.

69. UICN France; MNHN; SHF. La Liste rouge des espèces menacées en France-Chapitre reptiles et amphibiens de France métropolitaine; UICN: Paris, France, 2015. Available online: https://inpn.mnhn.fr/docs/LR_FCE/UICN-LR-Reptile-Fascicule-m5-1.pdf (accessed on 27 February 2019).

70. Denoël, M. Newt decline in Western Europe: Highlights from relative distribution changes within guilds. Biodivers. Conserv. 2012, 21, 2887-2898. [CrossRef]

71. Dimancea, N.; David, A.; Cupsa, D.; Cicort-Lucaciu, A.-S.; Indrei, C. The trophic spectrum analysis of a Pelophylax ridibundus population from Scăpău locality, Mehedinți county, SW of Romania. Muz. Olten. Craiova Oltenia. Studii Comunicări. Ştiinţele Naturii 2010, 26, 177-181.

72. Paunovic, A.; Bjelic-Cabrilo, O.; Simic, S. The diet of water frogs (Pelophylax esculentus 'complex') from the Petrovaradinski Rit marsh (Serbia). Arch. Biol. Sci. 2010, 62, 797-806. [CrossRef]

73. Denoël, M. Seasonal variation of morph ratio in facultatively paedomorphic populations of the palmate newt Triturus helveticus. Acta Oecol. 2006, 29, 165-170. [CrossRef]

74. Cohen, J.E.; Pimm, S.L.; Yodzis, P.; Saldana, J. Body sizes of animal predators and animal prey in food webs. J. Anim. Ecol. 1993, 62, 67-78. [CrossRef]

75. Duellman, W.E.; Trueb, L. Biology of Amphibians, 2nd ed.; Johns Hopkins University Press: Baltimore, MD, USA, 1994.

76. Kraus, F. Alien Reptiles and Amphibians: A Scientific Compendium and Analysis; Springer: New York, NY, USA, 2009.

77. Preisser, E.L.; Bolnick, D.I.; Benard, M.E. Scared to death? The effects of intimidation and consumption in predator prey interactions. Ecology 2005, 86, 501-509. [CrossRef]

78. Courant, J.; Secondi, J.; Vollette, J.; Herrel, A.; Thirion, J.M. Assessing the impacts of the invasive frog, Xenopus laevis, on amphibians in western France. Amphib. -Reptil. 2018, 39, 219-227. [CrossRef]

79. Manenti, R.; Falaschi, M.; Monache, D.D.; Marta, S.; Ficetola, G.F. Network-scale effects of invasive species on spatially-structured amphibian populations. Ecography 2020, 43, 119-127. [CrossRef] 